\title{
QUESTIONS OF DRY VALLEYS IN KARST: CASE STUDY OF MALI DOL, KRAS (SLOVENIA)
}

\author{
VPRAŠANJE SUHIH DOLIN NA KRASU, PRIMER MALEGA DOLA, \\ KRAS (SLOVENIJA)
}

\author{
Jure KOŠUTNIK ${ }^{1}$
}

\begin{abstract}
UDC 911.2:551.435.83(497.4 Mali dol) Jure Košutnik: Questions of dry valleys in Karst: Case study of Mali dol, Kras (Slovenia)

In the article the geomorphology of the Mali dol dry valley is presented. It is one of at least two dry valleys that cross about $45 \mathrm{~km}$ long and up to $15 \mathrm{~km}$ wide Kras plateau. Mali dol is a 10 kilometers long, 50 to 75 meters deep dry valley. It meanders on the leveled surface across the Kras plateau in direction NESW, perpendicularly to all structures. Because of the sediment and thicker soil cover deep and large solution dolines inside the basic valley-like shape were formed. These dolines are larger and deeper than the dolines formed on the nearby surface of the plateau. Local tectonically crushed zones, limestones with cherts and thick sediment cover allow some overland flow into the valley. In such places some smaller but deep and steep erosion gullies were formed.

From the morphology, the position of the dry valley and the sediments we can infer the polygenetic origin of the valley. It was formed during the planation of Kras in the height of the piezometric level.
\end{abstract}

Keywords: Geomorphology, dry valley, karst planation, Mali dol.

\author{
Izvleček \\ UDK 911.2:551.435.83(497.4 Mali dol) \\ Jure Košutnik: Vprašanje suhih dolin na Krasu, primer Male- \\ ga dola, Kras (Slovenija)
}

$\mathrm{V}$ članku je predstavljena suha dolina Mali dol, ki je ena izmed suhih dolin, ki prečkajo $45 \mathrm{~km}$ dolgo in do $15 \mathrm{~km}$ široko uravnavo Krasa. Mali dol je $10 \mathrm{~km}$ dolga in med 50 in 75 metrov globoka suha dolina, ki meandrira po Komenskem Krasu v prečnodinarski smeri prečno na vse reliefne in geološke strukture. Zaradi sedimenta in debelejše odeje prsti so se $\mathrm{v}$ dno dolinaste oblike poglobile globoke in velike korozijske vrtače. Te vrtače so večje in globlje od vrtač na sosednjem, uravnanem kraškem površju. Lokalno pretrte cone, komenski ploščati apnenci $\mathrm{z}$ roženci in debela odeja sedimenta dovoljujejo površinsko odtekanje vode s pobočij v dno doline. Na nekaterih mestih so se zato oblikovali globoki in strmi erozijski jarki. Geomorfološke značilnosti, starost dolinske oblike in debelina sedimenta govorijo o poligenetskem nastanku suhe doline. Oblika je nastala med uravnavanjem platoja v višini piezometričnega nivoja.

Ključne besede: Geomorfologija, suha dolina, kraško uravnavanje, Mali dol.

\section{INTRODUCTION}

Kras, because of its historic importance for karstology, also called classical Kras and because it lies in the hinterland of Trieste also called Trieste Kras, is around 500 $\mathrm{km} 2$ big limestone plateau in SW Slovenia (Gams, 1974). Geologically Kras plateau is an anticlinorium leveled by a longer period of planation and denudation (Gams, 1974). It is part of the Dinaric Mountains.
In Mesozoic Kras was part of the dinaric carbonate platform. The oldest and most widely spread rocks on the surface of Kras are cretaceous limestones. In the smaller extent also Paleocene and lower Eocene limestones can be found. Result of the deepening of sedimentation environment (Jurkovšek, 1996) and erosion in Alps are thick Eocene flysch beds which covered SW Slovenia (Placer, 1981; Habič, 1984; Gams, 2003) and are the youngest rocks in the area.

\footnotetext{
${ }^{1}$ Petričeva 14, SI-1230-Ljubljana-Črnuče, jurekosutnik@gmail.com Received/Prejeto: 17.08.2007
} 


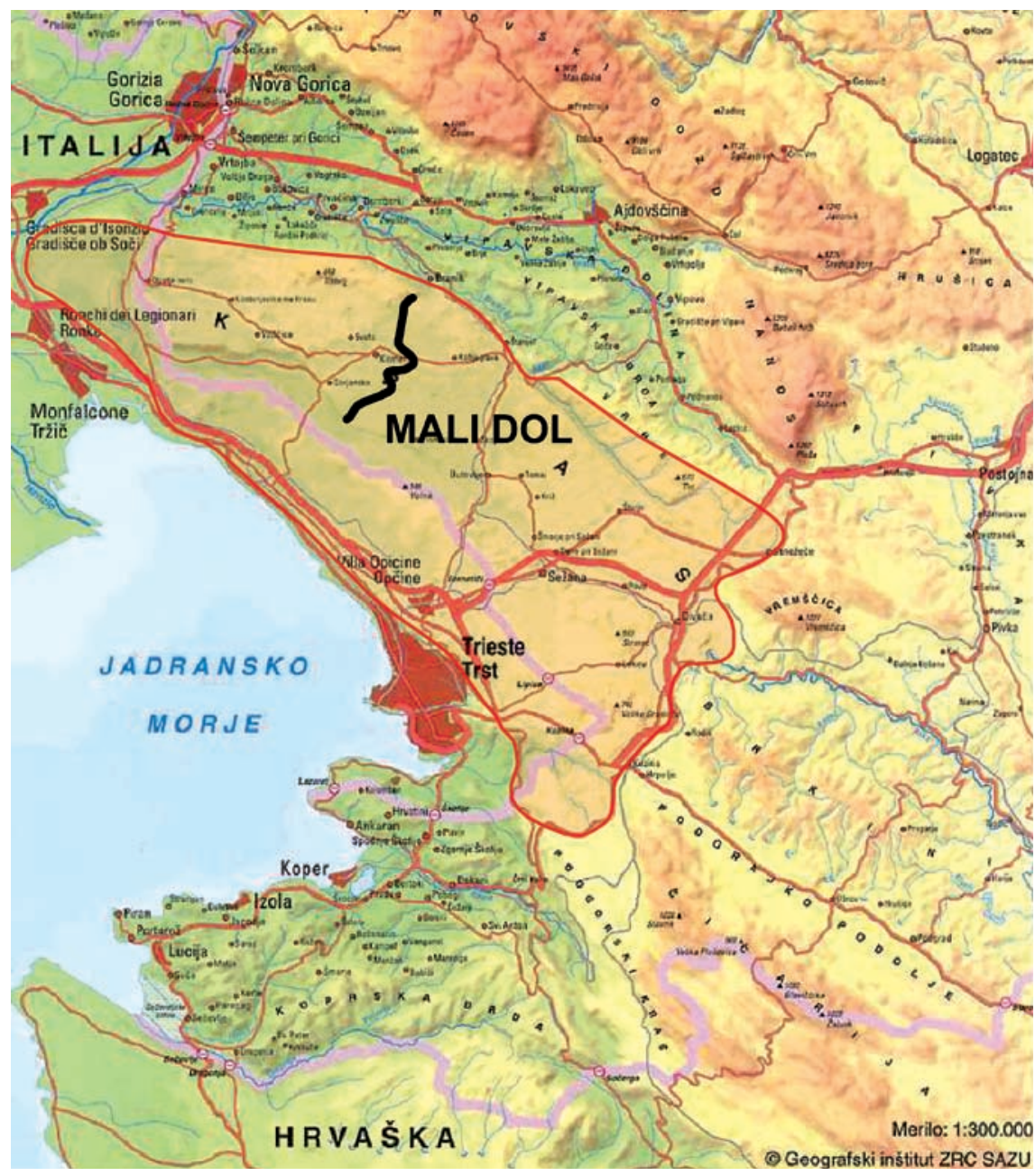

Fig. 1: Kras plateau with Mali dol dry valley (Slovenija: pokrajine in ljudje, 1999).

erosion seemed to be the most probable process that created the forms, also other possibilities were considered.

Karst has its beginning and its end, its history in which it goes through a variety of evolution phases. The definition of karst we know from the literature but if we take a historical timeline of a certain karst region and we slice it somewhere in its past evolution and analyze the state of the karst and make a definition out of our findings, we will many times find that our definition is just opposite of the one from the text books. If we are aware of this and if we know that karst is in a way conservative, that it to some extend preserves the surface forms, the combination of different historical land forms in karst surface is something we must seriously consider during our studies.

I can say that dry valleys are characteristic and important karst land form. Dry valleys appear also in the fluvial geomorphic system but their identification in karst is easier because of their longer life spend. Their importance lies in their key-role in

Kras inclines evenly from SE towards NW; from 435 meters above see level at Divača to 98 meters above sea level at Doberdo. Three higher elevation ridges, with heights above 450 meters are present (Slovenija: pokrajine in ljudje, 2001). Trstelj hills (Trstelj $643 \mathrm{~m}$ ), the northern most part of Kras borders with Vipava valley. The second ridge starts near Sesljan (Sistiana), it reaches the biggest heights above Trieste and continues into Slovenia. On the top of the middle ridge Volnik hills (Volnik $546 \mathrm{~m}$ ) the state border between Italy and Slovenia is running. Volnik hills divide two main plateaus, the narrower Nabrežina-Bazovica (Aurisina-Basovizza) and the wider Sežana-Komen plateau (Gams, 2003). Micro relief in Kras is represented in numerous dolines and scarce low, rounded hills. Depression forms are represented also with large rounded dolines of collapse origin and valleylike features, with additional, sometimes prolonged, solution dolines in the bottom.

The primary goal of the research was to determinate the origin of the valley-like features. Although fluvial interpretation of development of certain karst surface.

Researchers named dry valleys in Kras doli (singular: dol). Inhabitants of Kras use the expression dol for bigger dolines, which are common also in the bottom of dry valleys (Radinja, 1965). The word dol is of preslavic origin and meant cave, cavern, valley and also into the valley and into the cave (Snoj, 2003). Mali dol got its name after the village of the same name in its bottom, so we can distinguish it from Brestovica and Doberdo dry valleys.

For the purpose of understanding the processes in the dry valley-like form and its origin detailed geomorphologic mapping was done, which resulted in a geomorphologic map in the scale 1:5000 with legend.

Mali dol meanders on the leveled surface across Kras plateau in the direction NE-SW, perpendicularly to lithological and structural units of prevailing dinaric direction. It starts above Branica river valley with a pass in the Trstelj hills on 293 meters above sea level. It has a distinc- 



Fig. 2: Longitudinal profile of Mali dol dry valley. Geomorphologic mapping of Mali dol

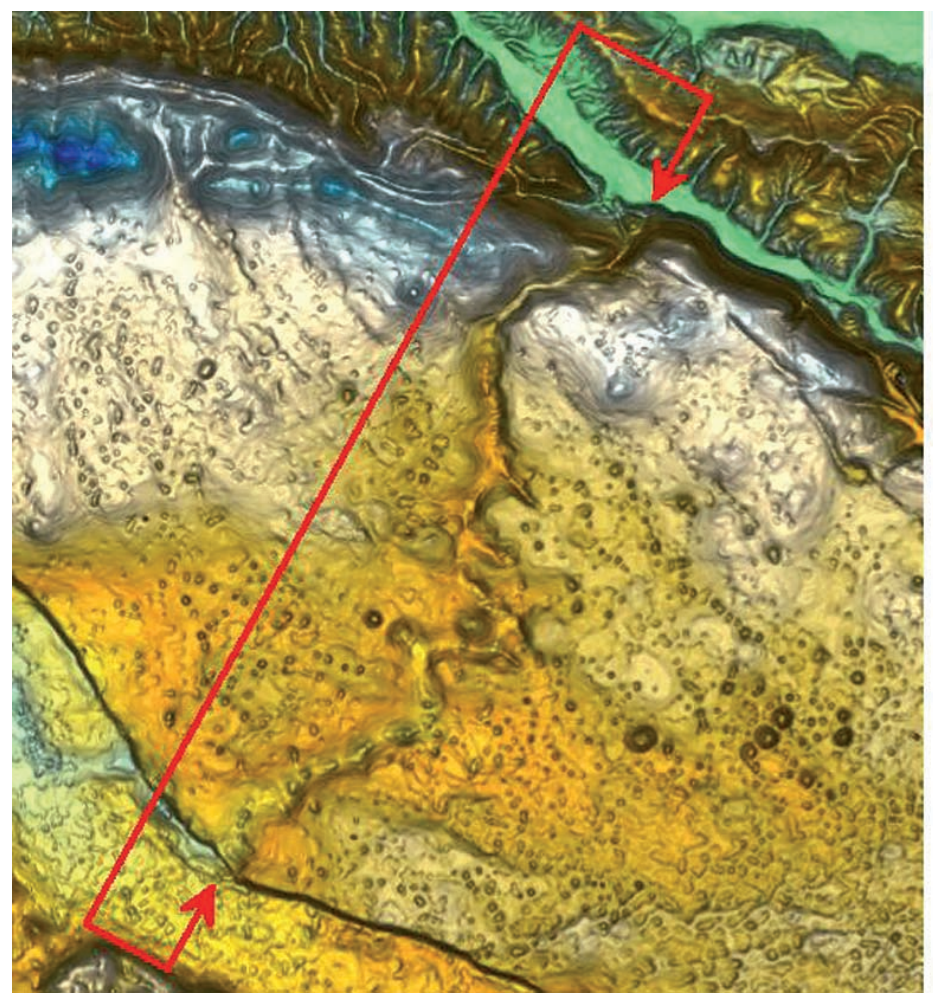

tive prolonged depressional shape, characteristic for river valleys. In its bottom large solution dolines were deepened. Transition between the surrounding planated karst surface and Mali dol is quick but not sharp. The difference in elevation between Komen plateau and the bottom of Mali dol is in its northern part 40, in its central part between 50 and 60 and in the southern part up to 75 meters. The bottom of the valley-like form is at its largest extent more than 250 and in its smallest extant only 40 meters wide. The total length of Mali dol is 10 kilometers.

In Mali dol, throughout its length the rocks are of upper cretaceous age. Between Tomačevica and Mali dol village characteristic thin-layered limestones with cherts can be found. At the edge of Kras anticlinorium in Trstelj hills also layers of Paleocene and Eocene age appear. On the opposite end of Mali dol in the Divača fault lower cretaceous limestones and dolomites appear (Osnovna geološka karta SFRJ, 1973). Age of rocks generally decreases in the NE direction.

\section{RELIEF FORMS IN MALI DOL}

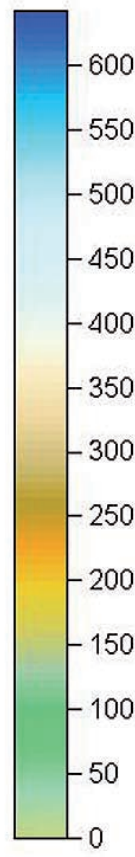

Evolution of relief forms in Mali dol presumably happened gradually, all forms are not of the same age and all forms were not made only by corrosion. The most important relief forms are dolines and erosion gullies.

Up to 20 meters deep solution dolines are deepened into valley's bottom. Dolines are in average wider than dolines on the surrounding karst plateau and usually prolonged in the general valley direction. Extremely wide irregular dolines can also be found in the bottom of Mali

Fig. 3: DEM of Mali dol and it's surrounding. 




Legend of the Geomorphologic map of mali dol, 1:5000

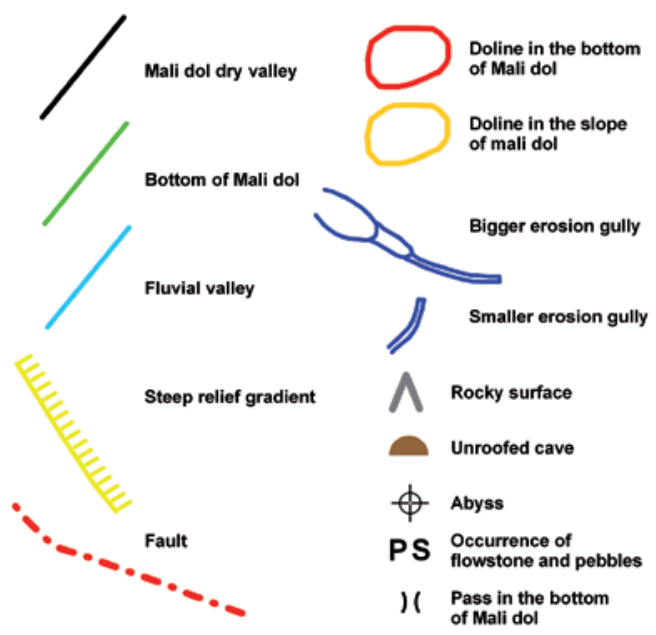

Fig. 5: Legend of the geomorphologic map.

on a square kilometer of planated surface near Komen and on the square kilometer of Mali dol is at a ratio of 5 to 1 .

In the slopes of Mali dol, in the slopes of dolines in the bottom of Mali dol and between dolines erosion gullies were developed. Bigger gullies are less steep and wider than smaller ones, commonly related to tectonically fractured

Fig. 4: Geological map of Mali dol (Osnovna geološka karta, list Gorica).

dol. According to their size we can call them uvalas but they can be also of collapse origin. The number of dolines


zones. Usually they end in dolines in the bottom of Mali dol, where alluvial fens were formed. Gullies in the slopes of Mali dol reach the planated Komen plateau and can still bee traced as a series of shallow dolines. Gullies were probably formed, because locally thicker, less permeable soil and sediment cover allows surface runoff. Evidence of that was commonly found. Surface water flow has an ability to carry sediment and organic particles from the plateau and slopes to the bottom of Mali dol.

Fig. 6: Part of the geomorphologic map of Mali dol (TTN 1:5000). 


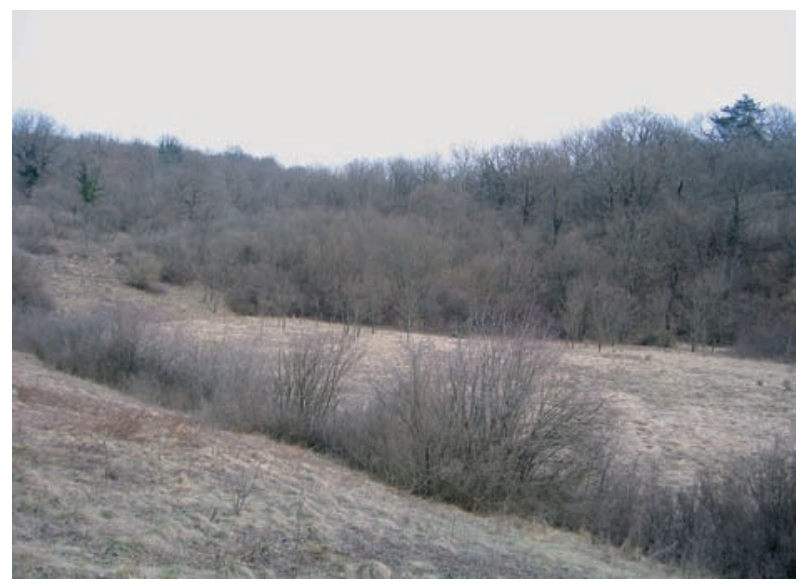

Fig. 7: Prolonged doline in the bottom of Mali dol.

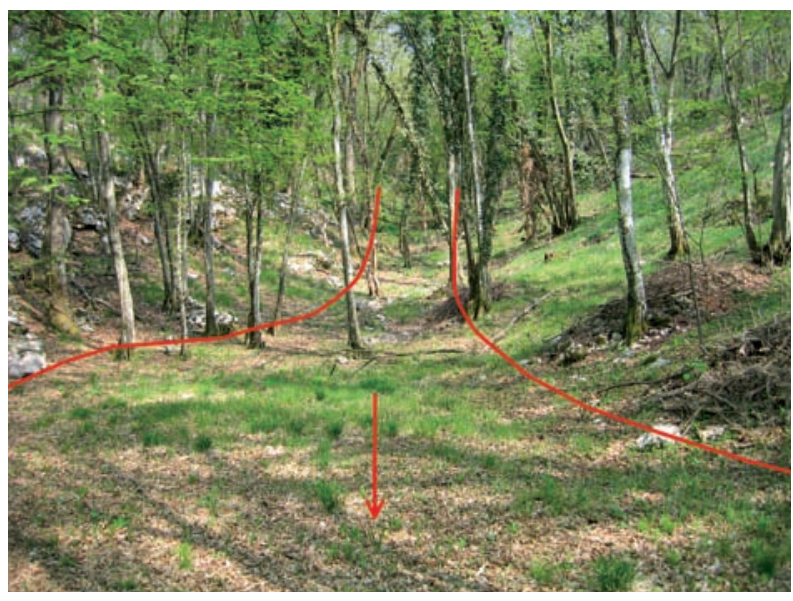

Fig. 9 and Fig. 10: Erosion gullies in the slopes of Mali dol.

\section{SEDIMENTS AND FLOWSTONE IN MALI DOL}

Bottom of Mali dol is covered by a thick layer of sediments and soil. At some locations in dolines, where peo-

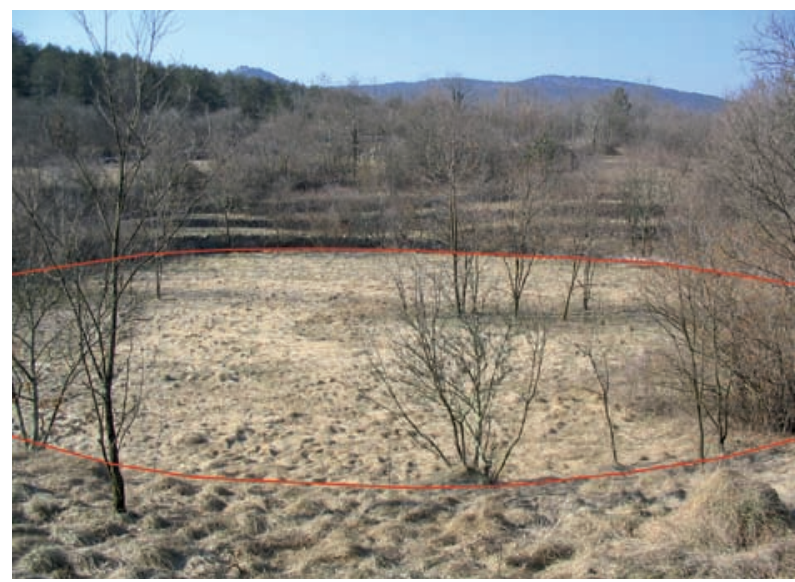

Fig. 11: Thick sediment in the bottom of Mali dol.

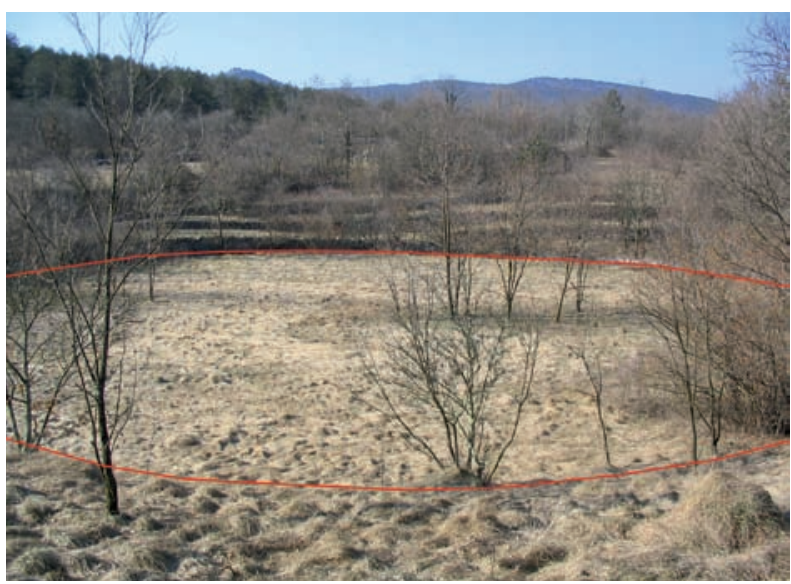

Fig. 8: Doline with anthropogenicaly changed bottom.

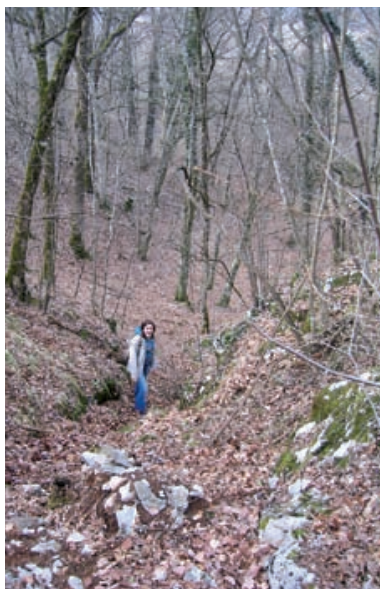

ple removed the sediments and used them elsewhere, even after several meters bedrock was not reached. The origin of the sediment is polygenetic. Part is the so called insoluble limestone residue, which is more important only where otherwise very pure limestone contains cherts. Origin of the other part of the sediment can be related with impermeable flysch layers, from which particles were brought

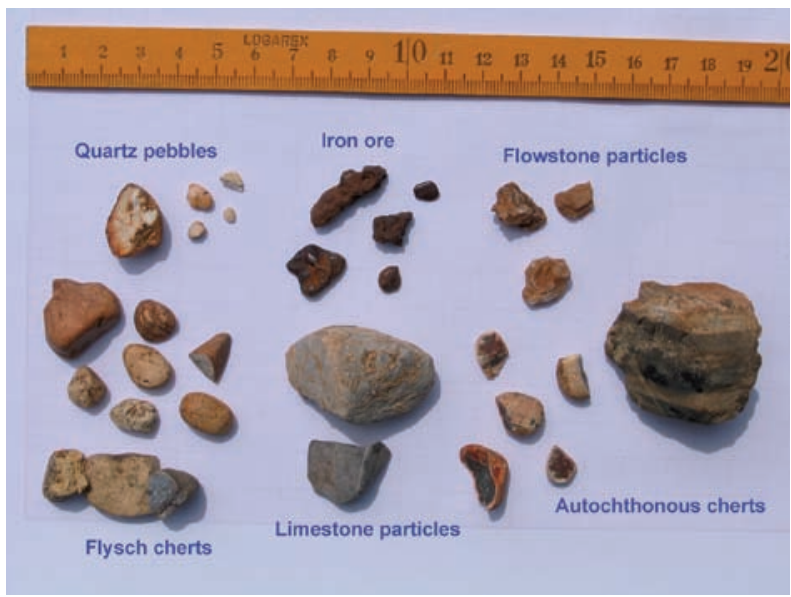

Fig. 12: Rock particles and pebbles found in the sediment.

on today already denudated karst surface by sinking streams. Two important processes are enabled by the sediment presence. Firstly it allows surface run-off with 
transportation to lower parts of the valley and formation of gullies. Secondly its capability of water retention increases the accelerated corrosion on the contact between sediment and limestone.

Alochtonous and autochthonous rock particles were found in the sediment of Mali dol. Autochthonous are the semi-rounded parts of chert rubble and some subcutaneously rounded limestone particles, both deriving from underling bedrock. Alochtonous rock particles are pebbles of quartz and cherts which were transported and rounded by sinking streams from flysch. Quartz pebbles are white, non-transparent and partly limonited. Chert pebbles, reddish to pale grey, almost white in color were made from flysch sandstone and have visible layers and grainy texture (Herlec, 2006). More or less rounded particles of limonite iron ore can be found.

All speleothem occurrences were noted because of the interpretation of the origin of the valley. Compact speleothem blocks were found twice, the first time in the Bobovec doline north of village Mali dol where denudation in the slope revealed a cave, possibly an abyss filled with cave sediments and flowstone. The second time flowstone was found NW of the village Škofi. A cave opens in the SE slope of doline called Jevščine. Distinctive yellowish cave sediment and thick speleothem come to the surface.

\section{THE QUESTION OF DEVELOPMENT, ORIGIN AND AGE OF MALI DOL}

According to older Slovene geomorphologists Mali dol was created by fluvial erosion in the so called "pre-karst phase « of surface development. The valley is a remnant of the last phase of river down-cutting before it gradually sinked underground in correlation with sudden start of karstification process (Radinja, 1965). Gams wrote that Mali dol is the result of the last phase of tectonic lowering of the western part of Kras as a result of counter-clockwise rotation of the Adriatic micro plate and general tectonical lowering of Po river basin (Gams, 1998). Tectonical origin of the valley is also accepted by Habič. He wrote that Mali dol was created on the contact between different tectonical structures in association with the change in general ridge direction of Kras from dinaric (NW-SE) to alpine (W-E; Habič, 1984). In addition to possible fluvial and tectonical origin of Mali dol also the development from a denudated cave system should be considered.

By inspection of the geomorphologic map and by the method of exclusion we can state, that Mali dol, as we see it today, was made by fluvial erosion. Meandering shape excludes its tectonical origin, the lack of thick-bedded speleothems and unproportionaly smaller dimensions of the largest Slovene unroofed cave (unroofed cave in Loza) exclude its unroofed development. Only explanation by the fluvial erosion development remains. The valley-like feature Mali dol in Kras was at some time in the past an active river valley which is now dry.

\section{CONCLUSION}

Already in the early stages of research preparation, it became clear that the task is going to be harder than expected. In a seemingly simple equation new, puzzling variables emerged.

Buy geomorphic mapping polygenetic origin of Mali dol was confirmed. Different processes, acting one by another and simultaneously, have affected the creation and later development of Mali dol during longer period of time. All affective geomorphic processes are closely connected with sediments. Less permeable sediment, whether it is insoluble limestone residue, remnant of Eocene flysch cover or filling of denudated caves, has a key role in the geomorphological development of Mali dol. The sediments impermeability, thickness and retention capability affected the accelerated corrosion process and contributed to preservation of the land form.

Numerous questions remain open. The time-line, age of planation, beginning of the last phase of karstification and the valley formation should be confirmed with absolute datations. As far as we know the most promising datation method is paleomagnetism which already gave some results on the age of cave sediments in Slovenia. New data about tectonic activity on the Miocene/Pliocene border is being gathered, along with possible gradient changes on Kras during the messinian crisis and mineralogical characteristic of karst sediments. Specific accelerated corrosion impact and detailed sediment characteristic of Mali dol are jet to be studied. 


\section{ACKNOWLEDGEMENT}

This article is part of my diploma thesis presented at Geography department of Ljubljana University. I would like to thank Dr. Andrej Mihevc for guidance and support.

\section{REFERENCES}

Državna topografska karta RS 1:25 000. 145 Opatje selo, 1996. 1. izd. 1:25 000. Ljubljana, Republika Slovenija - Ministrstvo za obrambo in Ministrstvo za okolje in prostor, Geodetska uprava RS.

Državna topografska karta RS 1:25 000. 127 Miren. 1997. 1. izd. 1:25 000. Ljubljana, Republika Slovenija Ministrstvo za obrambo in Ministrstvo za okolje in prostor, Geodetska uprava RS.

Gams. I., 1974: Kras.-Slovenska matica, p. 359, Ljubljana.

Gams, I., 1986: Kontaktni fluviokras.-Acta carsologica, 14/15, 71-87, Ljubljana.

Gams, I., 1998: Geomorphogenetics of the Classical Karst - Kras.-Acta carsologica, 17, 2, 181-198, Ljubljana.

Gams, I., 2003: Kras v Sloveniji.-Založba ZRC, ZRC SAZU, p. 516, Ljubljana.

Gregorič, A., 2005: Analiza razvoja paleonapetosti v dinarskem narivnem sistemu zahodne Slovenije (okolica Nove Gorice).-Univerza v Ljubljani, NTF, Oddelek za geologijo, p. 84, Ljubljana.

Habič, P., 1984: Reliefne enote in strukturnice matičnega Krasa.-Acta carsologica, 12, 5-26, Ljubljana.

Habič, P., 1986: Površinska razčlenjenost Dinarskega Krasa.-Acta carsologica, 14/15, 39-58, Ljubljana.

Herlec, U., 2006: Litološka sestava proda.-Personal source, Ljubljana.

Jurkovšek B., et al, 1996: Formacijska geološka karta južnega dela Tržaško-komenske planote.-Inštitut za geologijo, geotehniko in geofiziko, p. str, Ljubljana

Kras, pokrajina-življenje-ljudje. 1999. Kranjc, A., (ur.). Ljubljana, Založba ZRC, ZRC SAZU, 321 str.

Mihevc, A., 1999: Pomen brezstropih jam za geološko, geomorfološko in geografsko proučevanje krasa.Geološki zbornik, 14, 27-29, Ljubljana.

Osnovna geološka karta SFRJ. Tolmač lista Gorica. 1973. Beograd, Zvezni geološki zavod, 50 str.

Osnovna državna karta, SR Slovenija 1:5 000. B22 Komen 19. 1968. 1:5 000. Ljubljana, Zvezna geodetska uprava SFRJ.

Placer, L., 1981: Geološka struktura jugozahodne Slovenije.-Geologija, 24, 1, 27-60, Ljubljana.
Radinja, D., 1965: Nova morfogenetska dognanja na Krasu.-Univerza v Ljubljani, Oddelek za geografijo, p. 133, Ljubljana.

Radinja D., 1966: Morfogenetska problematika matičnega Krasa.-Geografski obzornik, 13, 3-4, 108-114, Ljubljana.

Radinja D., 1974: Matični Kras v luči širšega reliefnega razvoja. Acta carsologica, 6, 22-33, Ljubljana.

Slovenija: pokrajine in ljudje. 2001. Perko, D., Orožen Adamič, M. (ur.). Ljubljana, Založba Mladinska knjiga, 735 str.

Snoj, M., 2003: Slovenski etimološki slovar. 2. pregledana in dopolnjena izd.-Modrijan, p. 1022, Ljubljana.

Šebela, S., 1999: Kras v geološki preteklosti. V: Kras, pokrajina-življenje-ljudje, Kranjc, A., (ur.). Ljubljana, Založba ZRC, ZRC SAZU, str. 19-25.

Šušteršič, F., 1998: Interaction between a cave system and the lowering karst surface case study: Laški ravnik.Acta carsologica, 27, 2, 115-138, Ljubljana.

Temeljni topografski načrt, SR Slovenija 1:5 000. B22 Komen 28. 1981. 1:5 000. Ljubljana, Geodetska uprava SRS.

Temeljni topografski načrt, SR Slovenija 1:5 000. B22 Komen 29. 1981. 1:5 000. Ljubljana, Geodetska uprava SRS.

Temeljni topografski načrt, SR Slovenija 1:5 000. B22 Komen 37. 1981. 1:5 000. Ljubljana, Geodetska uprava SRS.

Temeljni topografski načrt, SR Slovenija 1:5 000. B22 Komen 38. 1981. 1:5 000. Ljubljana, Geodetska uprava SRS.

Temeljni topografski načrt, SR Slovenija 1:5 000. B22 Komen 47. 1981. 1:5 000. Ljubljana, geodetska uprava SRS.

Temeljni topografski načrt, SR Slovenija 1:5 000. B22 Komen 48. 1981. 1:5 000. Ljubljana, geodetska uprava SRS. 
